\title{
Energy Efficiency in the Romanian Industry
}

\section{Roxana CLODNITCHI ${ }^{1}$}

\begin{abstract}
Romania's energy intensity is almost double compared to the EU average. The country is the sixth most energy-intensive country in the EU-28 and there is a great need for energy efficiency in all economic sectors. Energy efficiency represented a significant part of each of Romania's energy strategies over the past decades. In order to achieve the goals set out here, many measures have been taken to increase efficiency in all areas of the country's economy. Economic growth has apparently decoupled from energy consumption. However, this fact can be rather explained due to the structural change of the economy towards tertiarization and low energy intensity industries. The present article presents a critical overview of the development of Romania and it's economic sectors with regard to their energy intensity. It addresses both economic and political and legal frameworks, with a focus on energy policy. Special attention will be given to industry, with a focus on energy-intensive industrial sectors.
\end{abstract}

Keywords: decoupling, energy efficiency, energy intensity, industrial energy consumption, resource intensity

\section{JEL classification: O13, P18, Q48}

DOI: $10.24818 / \mathrm{RMCI} .2018 .5 .516$

\section{Introduction}

At the end of 2016, the European Commission launched a new set of measures aiming to keep the European Union competitive as the clean energy transition is changing global energy markets, namely the "Winter Package". "Putting energy efficiency first" is one of the three main pillars of the Commission's proposal next to Providing a fair deal for consumers and achieving global leadership in renewable energies. 2015 Romania's energy intensity was $88 \%$ higher than the EU average, consuming according to Eurostat av. 226 kilograms of oil equivalent (EUR) / EUR 1000 GDP generated. There is a great need for energy efficiency measures. A reduction in energy intensity has been noted in recent years, but the potential remains high.

The table below shows the evolution of energy intensity in Romania, the EU 28 and in some selected EU countries. This is measured by the gross domestic consumption of energy per 1,000 units of gross domestic product at constant prices.

1 Roxana Clodnițchi, The Bucharest University of Economic Studies, Email: roxana.clodnitchi@fabiz.ase.ro, Telephone: 0040744519745 
Table 1. Energy intensity of the Romanian economy

\begin{tabular}{|c|c|c|c|c|c|c|c|c|c|c|c|}
\hline geoltime & $\mathbf{1 9 9 5}$ & $\mathbf{2 0 0 6}$ & $\mathbf{2 0 0 7}$ & $\mathbf{2 0 0 8}$ & $\mathbf{2 0 0 9}$ & $\mathbf{2 0 1 0}$ & $\mathbf{2 0 1 1}$ & $\mathbf{2 0 1 2}$ & $\mathbf{2 0 1 3}$ & $\mathbf{2 0 1 4}$ & $\mathbf{2 0 1 5}$ \\
\hline Bulgaria & $:$ & 593,2 & 542,8 & 509,2 & 463,9 & 464,9 & 490,1 & 467,8 & 426,3 & 445,5 & 448,5 \\
\hline Eastland & 696,4 & 331,1 & 344,4 & 352,2 & 372,0 & 417,9 & 390,4 & 370,3 & 400,2 & 387,7 & 358,0 \\
\hline $\begin{array}{c}\text { Czech } \\
\text { Republic }\end{array}$ & 400,5 & 314,4 & 297,3 & 283,9 & 280,6 & 290,5 & 274,5 & 274,9 & 276,4 & 261,2 & 251,0 \\
\hline Hungary & 376,8 & 266,2 & 258,9 & 254,8 & 257,4 & 270,5 & 260,4 & 251,4 & 238,2 & 227,7 & 233,6 \\
\hline Poland & 518,7 & 318,2 & 297,1 & 288,2 & 270,6 & 278,3 & 265,3 & 252,8 & 250,3 & 233,3 & 227,3 \\
\hline Romania & 550,9 & 342,1 & 318,8 & 293,0 & 278,3 & 282,5 & 285,4 & 274,4 & 243,0 & 233,8 & 226,7 \\
\hline EU 28 & 172,9 & 145,1 & 138,5 & 137,5 & 135,5 & 137,7 & 130,4 & 130,0 & 128,3 & 121,6 & 120,4 \\
\hline Germany & 159,3 & 139,7 & 128,5 & 128,4 & 127,7 & 128,9 & 118,1 & 118,3 & 120,2 & 114,2 & 112,6 \\
\hline Ireland & 141,5 & 90,3 & 88,8 & 91,5 & 90,6 & 90,7 & 83,0 & 83,3 & 82,1 & 74,9 & 62,0 \\
\hline
\end{tabular}

It can be seen that in the period 2006-2015 the energy intensity of the Romanian economy has decreased by $33.8 \%$ (almost double the EU average). On the other hand, the Romanian economy was still almost twice as energy-intensive in 2015 than the EU average.

Burcea, Ungureanu and Bâldan analyze the relationship between the energy intensity of the European economies and their growth, and presented some evidence that it is possible to decouple energy consumption from economic growth (Burcea, Ungureanu, \& Bâldan, 2012). Although investments have been made to increase energy efficiency, there is still a great deal of investment potential in this area.

\section{Context - Romania's Energy Balance}

Romania is an important producer of natural gas, oil and coal. Domestic production covers approx. $83 \%$ of own primary energy demand.

With a tradition of over 150 years in the production of crude oil and natural gas, Romania is the only significant producer of hydrocarbons in South-eastern Europe. Against the backdrop of the natural decline in deposits, annual production has steadily declined over the past decade to reach 3.8 million tonnes of crude oil and 10.8 million $\mathrm{m} 3$ natural gas in 2015. Proven oil reserves were 38.4 million tonnes in 2015 and gas reserves were 101.4 billion. m3. In 2015, domestic oil production covered about $40 \%$ of demand. The sharp decline in oil prices in 2014 has significantly reduced investment in this industry, resulting in lower production volumes. With the current exploitation rhythm, the oil reserves known in Romania will be exhausted in 10 to 12 years.

Coal is another important component of Romania's energy mix, it is considered to be key pillar of national energy security. In times of extreme weather conditions in summer and winter, coal-fired power plants cover up to one third of the electricity demand. Romania has a total of 12.6 billion tonnes of lignite, with an average calorific value of $1,800 \mathrm{kcal} / \mathrm{kg}$, concentrated geographically in Oltenia. The developed sources amount to 986 million t. The annual production of lignite fell 
from 31.6 million tonnes in 2012 to 22.1 million tonnes in 2015. Romania is thus in sixth place in the EU ranking - after Germany, Poland, Greece, the Czech Republic and Bulgaria. The reserves of hard coal in the Jiu Valley amount to 2.2 billion tonnes, of which 592 million tonnes are tapped. The calorific value of Romanian hard coal is $3,650 \mathrm{kcal} / \mathrm{kg}$. Coal production in 2015 was 1.29 million tonnes, down from 1.87 million tonnes in 2012. Both domestic coal producers are in a critical economic situation: several bankruptcy suits have been filed against Complexul Energetic Hunedoara; The lignite-mining company Complexul Energetic Oltenia also underwent restructuring and technological modernization.

Approximately $30 \%$ of the domestic consumption of primary energy is covered by natural gas. The large proportion can be explained by the relatively high availability of domestic resources, by its low environmental impact and by the ability to flexibly balance electricity from non-constant renewable sources (wind and solar). The existing infrastructure for extraction, transport, storage, distribution and underground storage is also at a good level of development nationwide. The natural gas market is favored by Romania's position in terms of transmission capacity in south-eastern Europe and the possibility of connecting to the Central European transport system and gas resources from the Caspian Basin. In 2015, natural gas production exceeded $95 \%$ of domestic consumption. In recent years, constant domestic production and decreasing consumption have led to a reduction in gas imports from 15\% in 2013 to $7.5 \%$ in 2014 and 2.5\% in 2015. However, in 2016, due to the fall in oil prices, import prices have fallen below production prices - so that domestic production was declining.

Domestic consumption of natural gas has stabilized in recent years after a period of severe decline. In 2015, consumption measured at the lowest calorific value (PCI) was $73.6 \mathrm{TWh}$, of which $9 \mathrm{TWh}$ was used as a basis for chemical fertilizers. The remaining 64.6 TWh were used for energy purposes: 29 TWh in industry; 10 $\mathrm{TWh}$ for heating in commercial and public institutions, including $0.8 \mathrm{TWh}$ in the agricultural sector; 25.6 TWh in households. An important part of natural gas is used in Romania for the production of electricity and heat in high capacity CHP plants. 37.5 TWh were used in 2015 in the production of electricity and heat or in the exploration, production, transport and distribution of fossil fuels.

Romania used to have a well-developed district heating system. The promotion of centralized heating systems, since they have a higher energy efficiency in consumption, should be promoted in national strategies (Leca, 2015).

Romania has a solid experience of a complete nuclear cycle, developed with Canadian CANDU technology. The uranium dioxide (UO2) used for the production of fuel for the two existing units (owned by Nuclearelectrica), which are cooled and operated with heavy water (HWR, heavy water moderated), is a product of processing and refining of domestic production of uranium. In 2016, after the closure of the Crucea Botusana deposit (jud. Suceava), Compania Naţională a Uraniului entered a restructuring process with the prospect of opening up new uranium deposits. Nuclearelectrica is currently buying raw materials from foreign markets to produce nuclear fuel at its factory in Pitesti. 
The share of renewables in the total consumption of Romania's primary resources today depends very much on production in the large hydropower plants and on the use of solid biofuels in individual households. In 2016, 29.8\% of the electricity produced in Romania came from hydropower plants. Regarding the biomass used for heating, hot water preparation and food preparation, the data are very controversial.

Until the present. many studies have dealt with the relationship between economic growth and energy and carbon intensity of economies such as Lise and Montfort, Bartleet and Gounder, Costantini and Martini or Menegaki in different countries and applying different modeling methods (Bartleet \& Gounder, 2010; Costantini \& Martini, 2010; Lise \& Van Montfort, 2007; Menegaki, 2011). Menegaki (Menegaki, 2013a, 2013b) shows that countries with remarkable performance in renewable energy production have average or low energy efficiency, while Europe's "delays" in renewable energy are the most efficient economies.

Table 2. Comparison of coverage of Romanian primary energy demand in ktoe (INS 2014 \&2017)

\begin{tabular}{|c|c|c|c|c|c|c|c|c|c|c|}
\hline Year & 2007 & 2008 & 2009 & 2010 & 2011 & 2012 & 2013 & 2014 & 2015 & 2016* \\
\hline $\begin{array}{l}\text { Primary } \\
\text { energy }\end{array}$ & 47.460 & 48.166 & 42.729 & 42.467 & 42.429 & 41.728 & 39.244 & 40235 & 40.769 & 40.960 \\
\hline \multicolumn{11}{|l|}{ of which: } \\
\hline Production & 27.300 & 28.779 & 28.034 & 27.428 & 27.465 & 27.112 & 25.853 & 26.314 & 26.387 & 24.001 \\
\hline Import & 17.399 & 16.324 & 11.235 & 11.239 & 11.570 & 11.615 & 9.993 & 10757 & 11333 & 12682 \\
\hline Production & 27.300 & 28.779 & 28.034 & 27.428 & 27.465 & 27.112 & 25.853 & 26.314 & 26.387 & 24.001 \\
\hline \multicolumn{11}{|l|}{ of which: } \\
\hline Coal & 6.858 & 7.011 & 6.477 & 5.903 & 6.661 & 6.345 & 4.656 & 4.448 & 4.711 & 4.217 \\
\hline Oil & 4.651 & 4.619 & 4.390 & 4.186 & 4.129 & 3.891 & 4.028 & 3.952 & 3.906 & 3.715 \\
\hline Gas & 9.075 & 8.982 & 8.964 & 8.705 & 8.724 & 8.770 & 8.687 & 8.854 & 8.874 & 7.350 \\
\hline Power & 3.264 & 4.233 & 4.242 & 4.618 & 4.286 & 4.101 & 4.591 & 5.195 & 5.096 & 5.198 \\
\hline Import & 17.399 & 16.324 & 11.235 & 11.239 & 11.570 & 11.615 & 9.993 & 10.757 & 11.333 & 12.682 \\
\hline \multicolumn{11}{|l|}{ Of which: } \\
\hline Coal & 3.021 & 2.030 & 640 & 540 & 596 & 765 & 594 & 498 & 546 & 521 \\
\hline Oil & 8.531 & 8.417 & 6.892 & 5.820 & 5.450 & 5.126 & 5.297 & 6.725 & 6.594 & 7.468 \\
\hline Gas & 3.904 & 3.567 & 1.614 & 1.834 & 2.489 & 2.321 & 1.177 & 470 & 163 & 1.185 \\
\hline Power & 109 & 79 & 56 & 66 & 89 & 121 & 39 & 93 & 325 & 307 \\
\hline
\end{tabular}

In the near future, not much will change in the Romanian dependence on primary energy imports. The extent of this dependency will be determined by the extent to which new usable resources can be found in the country, the level of integration of renewable energies and whether the future energy efficiency measures will be successful. The energy strategy provides for a balanced energy mix by 2030 . Imports of energy sources continue to be part of this strategy.

Not long ago, a gas field of 42 to 84 billion cubic meters was discovered in the Black Sea during the first deep water exploration well off the Romanian Black Sea coast. This is an important find as its size would cover six times the annual needs of Romania. The operator of deep-sea drilling in the Black Sea has been performed by ExxonMobil (www.exxonmobil.com) in collaboration with Petrom 
(www.petrom.ro). How this discovery could affect Romania's energy dependence is not yet known, but a significant reduction in imports could be achieved.

The subsequent table shows the Romanian reserves of fossil fuels.

Table 3. Fossil fuel reserves of Romania (MININD, 2007)

\begin{tabular}{|l|r|r|r|r|}
\hline \multirow{2}{*}{ Energy carrier } & \multicolumn{2}{|c|}{$\begin{array}{c}\text { Reserve } \\
\text { (Mil. t }\end{array}$} & $\begin{array}{c}\text { Yearly production } \\
\text { (Mil. toe) }\end{array}$ & \multicolumn{2}{c|}{$\begin{array}{c}\text { Approx. time to } \\
\text { depletion (years) }\end{array}$} \\
\hline Hard coal & 755 & 422 & 2,5 & 229 \\
\hline Brown coal & 1.490 & 276 & 3,0 & 47 \\
\hline Crude oil & 74 & 72 & 4,5 & 14 \\
\hline Natural Gas & 185 & 159 & 10,5 & 15 \\
\hline
\end{tabular}

From the above table it can be concluded that the primary energy production from fossil sources in Romania is secured for now. The expected growth of primary energy demand through the expansion of industry and production sites in Romania will in future be covered by increased use of renewable energy sources and, as before, imports of primary energy sources. The degree of dependency of energy imports will depend on the discovery of new usable internal resources, the degree of integration of renewables and the success of future energy efficiency measures, as well as economic development. There are no forecasts or expectations regarding the development of the future import share that we are aware of.

\section{The Romanian Industry and its Energy Intensity}

Romania is one of the EU countries with the largest share of industry in gross value added. Industry accounts for more than $25.7 \%$ of the gross value added, while financial services contribute 2016 with only $4.1 \%$. But the industrial sector however, is associated with a high energy consumption. With $29.4 \%$ of the total final energy consumption (excluding self-consumption of the energy industry), the industry is the second largest energy consumer in Romania. According to the Romanian National Statistics Office, in 2015, 33.7\% of final energy available for final consumption was allocated to households, followed by industry with $29.4 \%$ and transport with $25.5 \%$.

The following figure shows the breakdown of Romanian final energy consumption, the following chapter deals with the branches of industry. 


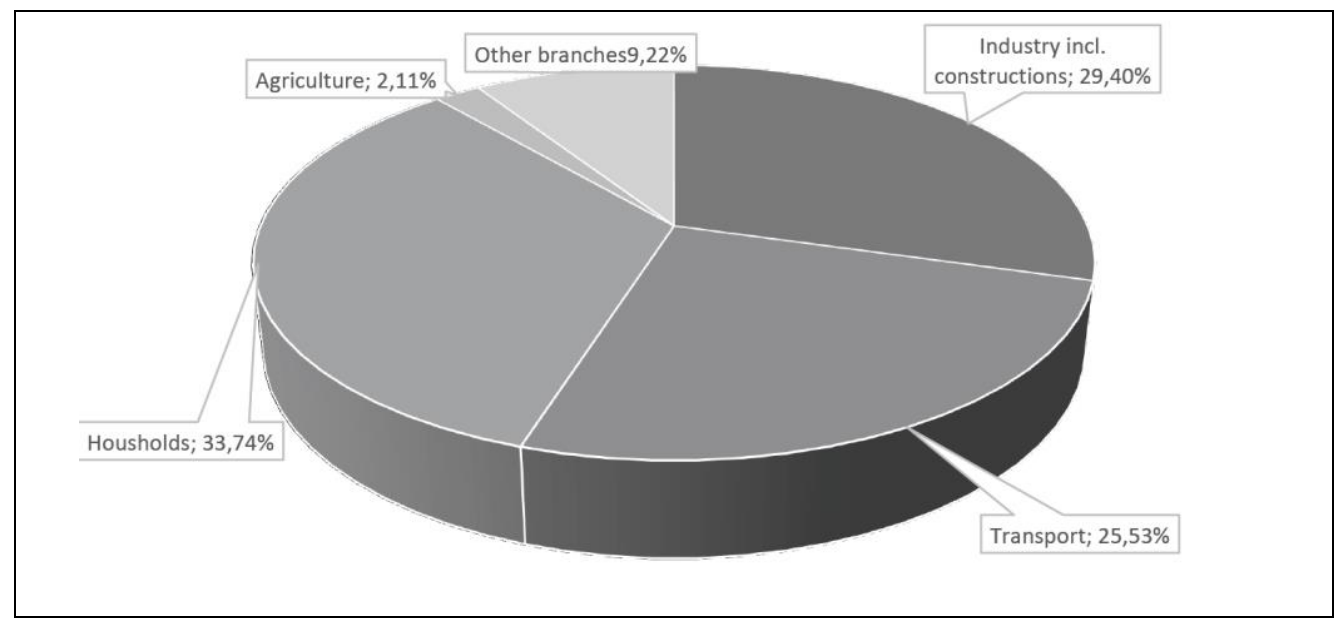

Figure 1. Distribution of final energy consumption in 2015 (INSSE, 2017)

In 2015, Romania had an energy intensity of $226,7 \mathrm{~kg} / \mathrm{EUR} 1,000,88 \%$ more than the EU average, twice the energy intensity of Germany and 3,65 times that of Ireland, the European leader for this indicator. The indicator shows the gross domestic consumption of energy per 1,000 units of gross domestic product at constant prices.

While it can be seen on the one hand that the energy intensity of the Romanian economy has halved since 1995 (while the EU has fallen by 43\% on average), on the other hand the Romanian economy is still 1.9 times more energyintensive than the EU average. However, this is a big step forward as the gap with the EU average has steadily declined in recent years. Also, economic growth has decoupled from energy consumption, a fact largely due to the structural change of the economy, as will be seen from the following interpretations.

Although energy consumption in the industrial sector has even fallen by $55 \%$ since 1995, by 2008 industry had the largest share of final energy consumption in the Romanian economy, accounting for $37 \%$ of total Romanian energy consumption. In 2009 , after a sharp decline in activities in the most energy-intensive sectors of the metalworking and chemical industries, industry's energy consumption was for the first time below the households' consumption, accounting for $27.8 \%$ of total final energy consumption. The trend has been maintained over the last few years: between 2010 and 2015, final energy consumption remained at about $29 \%$ and below the consumption of the population, which recorded an average consumption of $34 \%$ over the analysed period. According to the Romanian forecasting committee, this situation should not change until 2020 despite annual growth in energy consumption in industry (CNP, 2017)

Energy efficiency became a hot topic in the 2000-2005 period. Extensive studies are being undertaken to develop the Romanian Energy Efficiency Strategy 
2007-2010. Surveys at national level provided information on the stock of technologies and equipment. Investments should be specifically supported.

However, during the period 2005-2008, the economic boom meant that the administration was less interested in energy efficiency. Private investments were made independently of subsidies. In addition to the traditional industrial enterprises, which went through reengineering processes, there were many start-ups coming up. The administration lost track. Previous studies on the development of energy efficiency in the EU, such as Enerdata (http://germany.enerdata.net/), a database developed in collaboration with other European research institutes (http://eePotenzial.eu), were already 2010 very far away from the predicted course. Looking at the energy intensity of the total industry in 2004, this was $852 \mathrm{~kg} / \mathrm{EUR}$, in 2008 according to the Romanian Statistical Office it was $288 \mathrm{~kg} /$ EUR. Looking at actual consumption volumes, Romania has been far out of the planning scenario since 2013, as shown in the graph below provided by the Romanian Regulatory Agency.

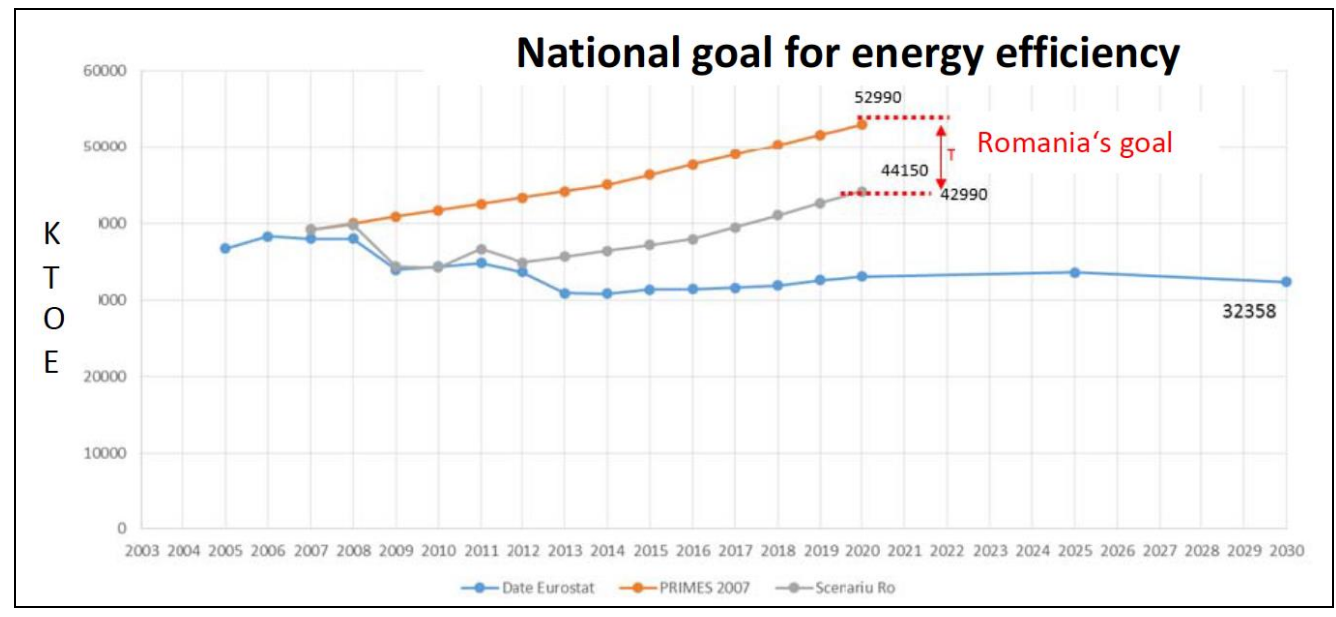

Figure 2. Objective and degree of target achievement with regard to energy consumption reduction - Europe 2020 (ANRE, 2017b)

In recent years, as a result of Romania's accession to the EU and the Great Depression, the promotion of efficiency and energy efficiency (from the diagnosis, to the definition of objectives and necessary measures, including implementation measures) and rational use of energy are becoming increasingly important. Particularly traditional industries, such as metalworking or, for example, the chemical industry, are characterized by a strong need for greater efficiency. Also, energy efficiency is not, as often claimed, the low hanging fruit in terms of investment efforts (Murafa, 2017). Like any other sub-sector it demands innovative financing instruments to ensure adequate scale-up.

Companies whose annual final energy consumption exceeds 1000 toe have the obligation to employ an accredited energy manager, who had to submit annual 
energy plans to the ANRE until 2014. From 2014, mandatory evaluations were also introduced for companies with lower energy consumption; The audits do not take place every year, but every four years. At present, there are about 450 industryaccredited energy managers in Romania. The graph below shows the number of energy auditors who have passed 2016 audits, the number of energy audits carried out and the frequency and extent of audits required by law.

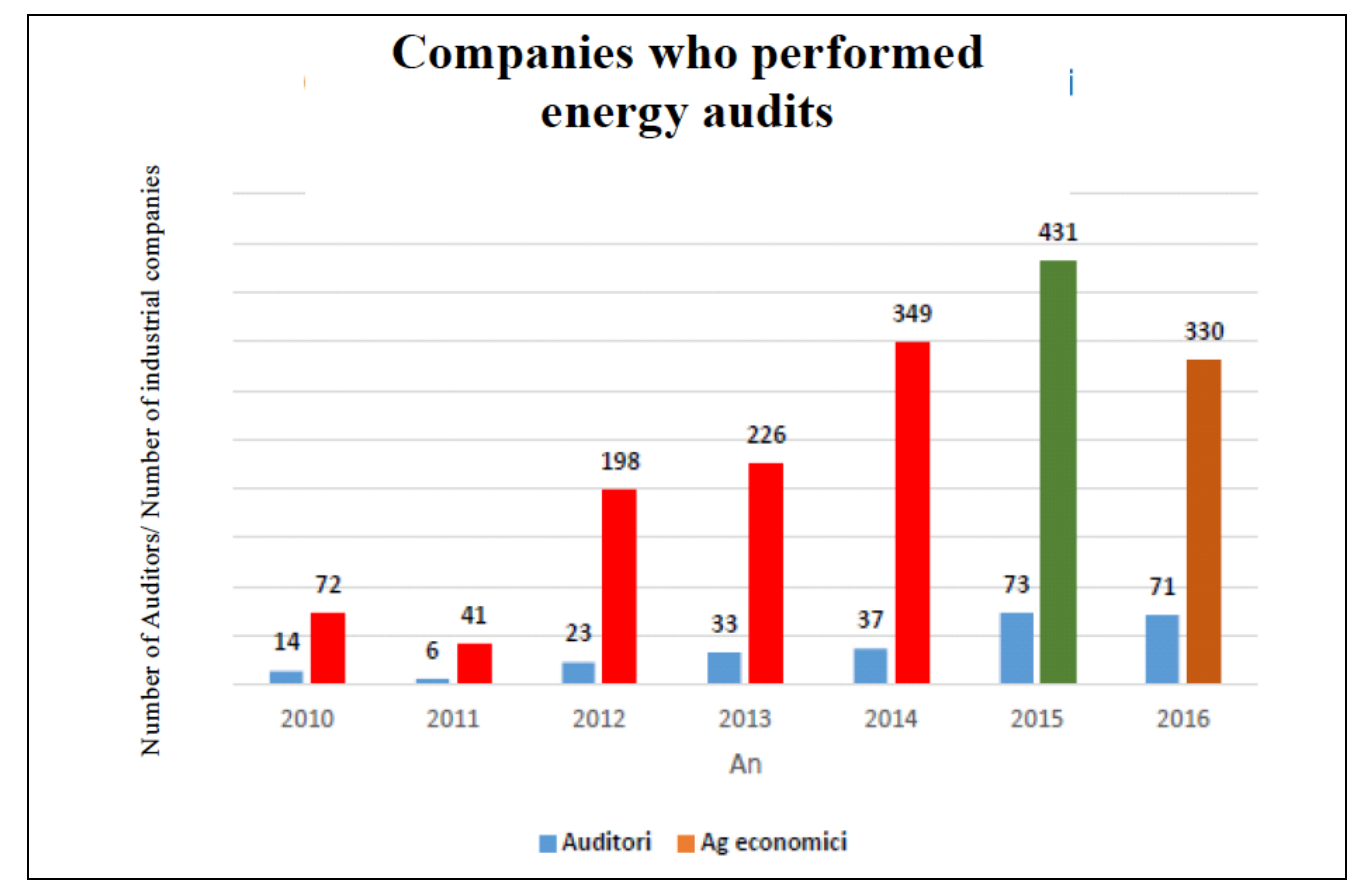

Figure 3. Energy audits of industrial companies (ANRE, 2017a)

Until 2016, the information provided by the energy managers through the energy audits was not centralized. The main aim of the ANRE when imposing this obligation was to improve the quality of the companies' energy efficiency plans. In the meantime, they have made part of the data available.

In 2016, 330 audits were performed - 68 for electrical energy, 33 for thermal energy and the remaining complex audits. The figure below shows the breakdown of 2016 energy audits into business activities. 


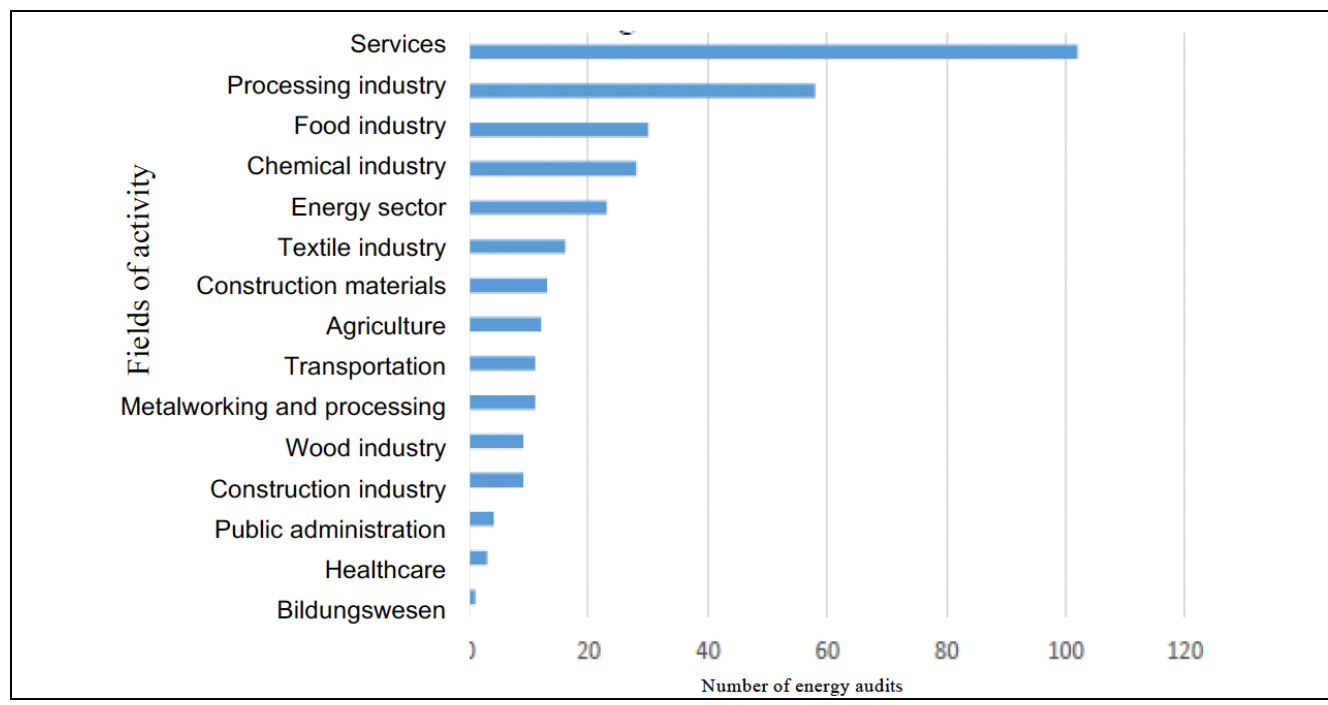

Figure 4. Number of performed energy audits by field of activity (ANRE, 2017a) audits.

The subsequent graph shows the savings potential that resulted from the

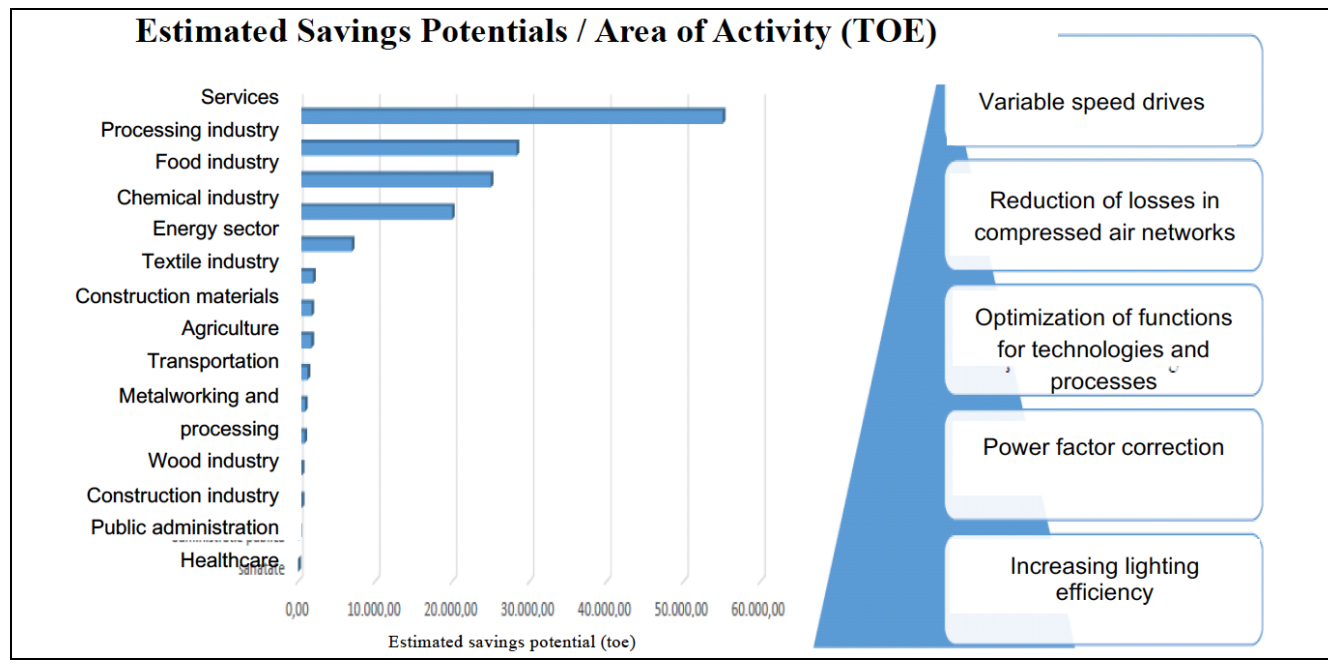

Figure 5. Energy savings potentials (ANRE, 2017a)

However, to implement these measures requires an investment of around EUR 500 million. Analyzing the statistically collected data as well as information from individual companies and associations, with a few exceptions, a decline in energy consumption in the industry will be noticeable. At first glance, consumption in the crisis years does not seem to have fallen spectacularly. However, if one also 
considers the development of the production volume and the added value in the branches, it is clear that targeted measures have already been taken to increase energy efficiency. Industrial added value more than doubled over the period 20042014 while energy consumption fell by about $42 \%$. Even in these circumstances, Romania is one of the most energy-intensive economies in Europe (1.8 times higher than the EU28 average). The tables and graphs below show the evolution of final energy consumption in industry and industrial value added.

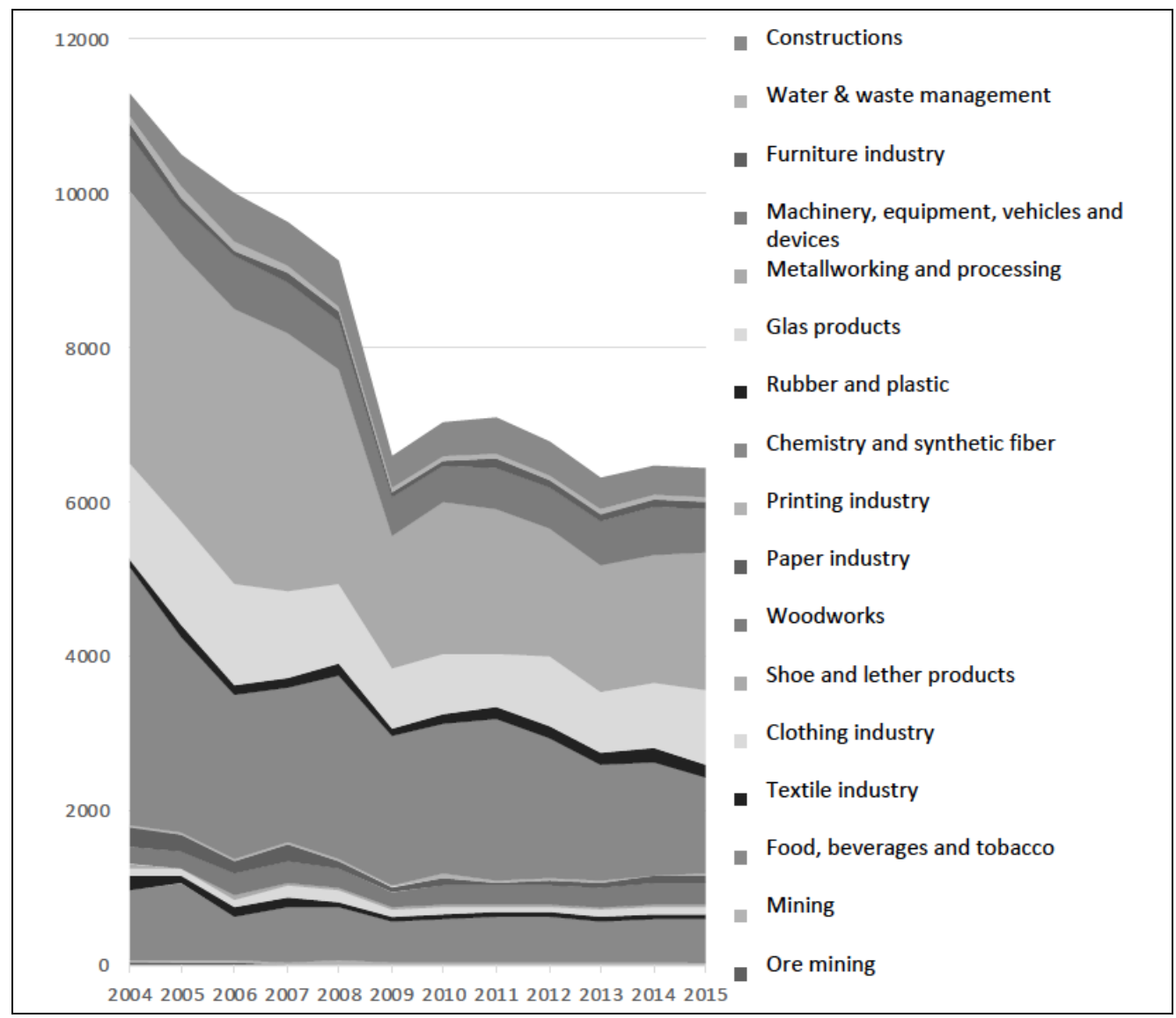

Figure 6. Energy consumption of the industry (ktoe) (INSSE, 2017) 


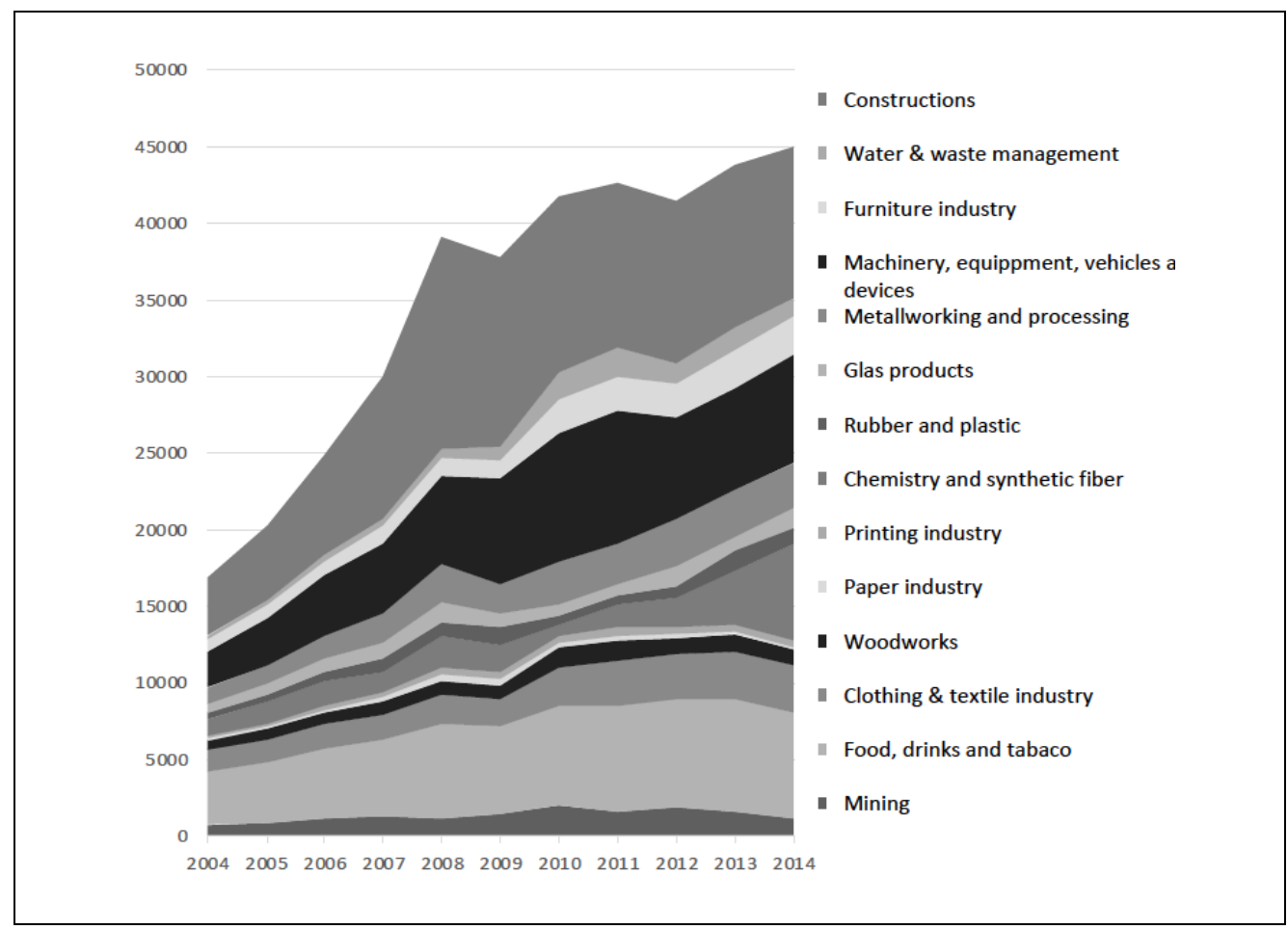

Figure 7. Value added (Mil. $€, 1$ EUR(2010)= 4,21RON) (INSSE, 2017)

When takeing a closer look at consumption, we notice that while heat consumption has fallen by about $44 \%$ since 2004 , electricity consumption has only fallen by about $18 \%$.

Table 4. Development of electricity and heat consumption of Romanian industry (INSSE, 2017)

\begin{tabular}{|l|l|l|l|l|l|l|l|l|l|l|l|l|}
\hline Year & $\mathbf{2 0 0 4}$ & $\mathbf{2 0 0 5}$ & $\mathbf{2 0 0 6}$ & $\mathbf{2 0 0 7}$ & $\mathbf{2 0 0 8}$ & $\mathbf{2 0 0 9}$ & $\mathbf{2 0 1 0}$ & $\mathbf{2 0 1 1}$ & $\mathbf{2 0 1 2}$ & $\mathbf{2 0 1 3}$ & $\mathbf{2 0 1 4}$ & $\mathbf{2 0 1 5}$ \\
\hline $\begin{array}{l}\text { Total energy } \\
\text { consumtion } \\
\text { (ktoe) }\end{array}$ & 11.285 & 10.505 & 9.998 & 9.630 & 9.115 & 6.612 & 7.020 & 7.093 & 6.796 & 6.307 & 6.456 & 6.438 \\
\hline $\begin{array}{l}\text { Power } \\
\text { consumption } \\
\text { (GWh) }\end{array}$ & 25.257 & 23.684 & 24.277 & 22.837 & 22.987 & 18.183 & 20.381 & 21.083 & 20.405 & 18.823 & 19.855 & 20.524 \\
\hline $\begin{array}{l}\text { Heat consumption } \\
\text { (TJ) }\end{array}$ & 20.054 & 14.867 & 14.847 & 12.885 & 13.545 & 9.947 & 11.834 & 12.200 & 11.668 & 10.830 & 11.130 & 11.320 \\
\hline
\end{tabular}


The table below shows the distribution of value added and final energy consumption in the industries in 2014. The latest data on industry contribution to gross value added date from 2014 and were published in the Romanian Statistical Yearbook 2016, which appeared in the first semester of 2017 is.

Table 5: Value added vs. industrial energy consumption 2015 (INSSE)

\begin{tabular}{|l|r|r|}
\hline & $\begin{array}{c}\text { Share of industrial } \\
\text { value added }\end{array}$ & $\begin{array}{c}\text { Share of industrial final } \\
\text { energy consumption }\end{array}$ \\
\hline Mining & $2,62 \%$ & $0,64 \%$ \\
\hline Food, beverages and tobacco & $15,41 \%$ & $8,74 \%$ \\
\hline Textil and clothing industry & $6,62 \%$ & $2,79 \%$ \\
\hline Woodworks & $2,27 \%$ & $4,28 \%$ \\
\hline Cellulose, paper and board production & $0,45 \%$ & $1,36 \%$ \\
\hline Printing industry & $0,89 \%$ & $0,25 \%$ \\
\hline Chemistry and synthetic fiber & $\mathbf{1 4 , 1 2 \%}$ & $\mathbf{2 2 , 8 3 \%}$ \\
\hline Plastics industry & $2,48 \%$ & $2,79 \%$ \\
\hline Other non-metal products & $\mathbf{2 , 7 9 \%}$ & $\mathbf{1 3 , 2 9 \%}$ \\
\hline $\begin{array}{l}\text { Metalworking and processing } \\
\text { industry }\end{array}$ & $\mathbf{6 , 4 0 \%}$ & $\mathbf{2 5 , 6 2 \%}$ \\
\hline $\begin{array}{l}\text { Machinery, equipment, vehicles, } \\
\text { devices }\end{array}$ & $15,96 \%$ & $9,48 \%$ \\
\hline Furniture industry & $5,35 \%$ & $1,30 \%$ \\
\hline Water and waste sector & $2,66 \%$ & $0,96 \%$ \\
\hline Construction industry & $21,98 \%$ & $5,68 \%$ \\
\hline
\end{tabular}

The metalworking, chemical and non-metal products (mainly building materials) industries are the largest consumers of energy among industrial sectors and at the same time account for a relatively small share of industrial added value. Because they are of strategic importance, they cannot be dispensed with in the foreseeable future. So energy efficiency measures are urgently needed in these industries. Other industries, such as The food industry has a greater share of value added and lower energy consumption, but is characterized by greater investment.

Looking at the industries based on their energy intensity, the next two figures are instructive. 


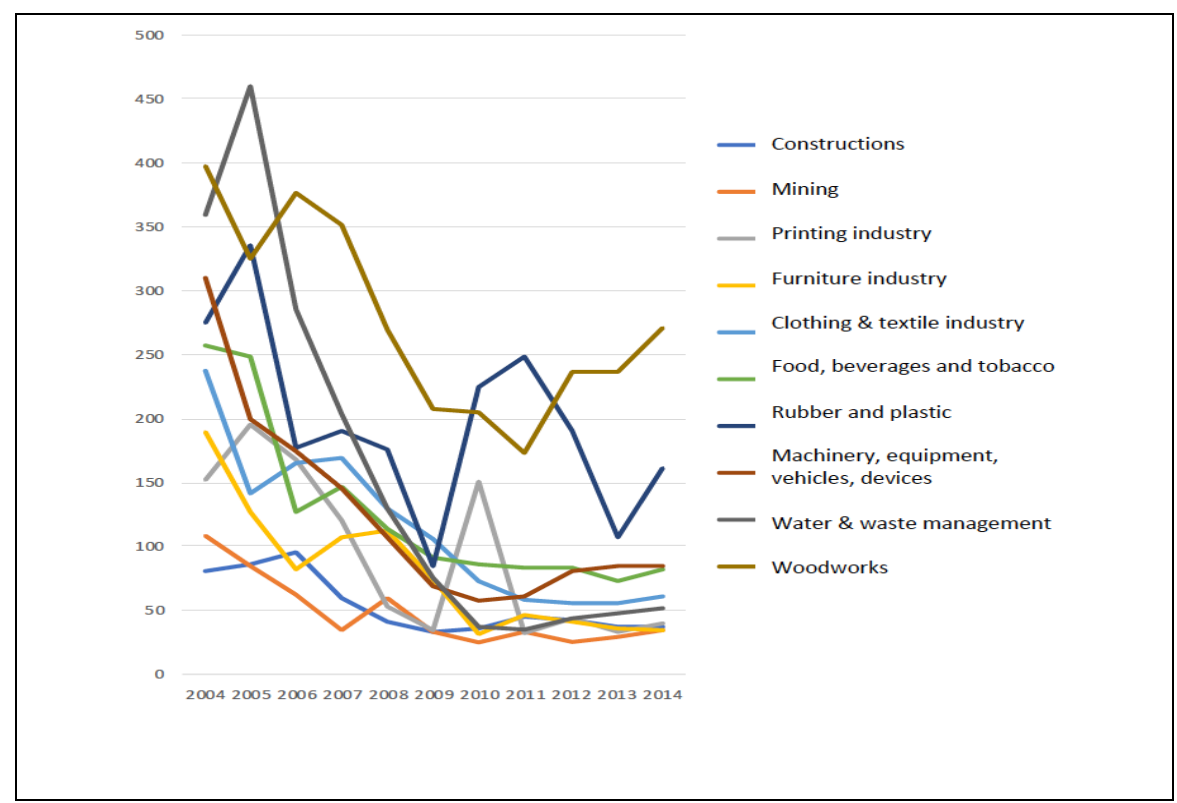

Figure 8: Energy intensity in the less energy intensive industries (ktOE / 1,000 EUR) (INSSE, 2017)

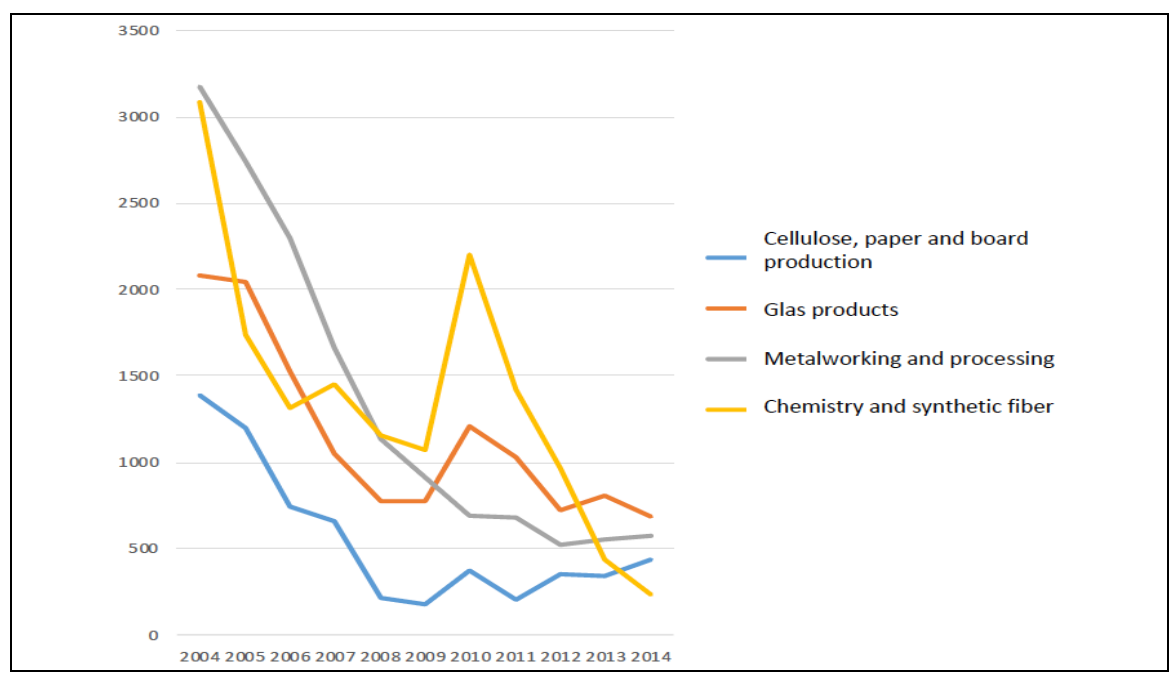

Figure 9: Energy intensity in the more energy intensive industries (ktOE / 1,000 EUR), (INSSE, 2017)

The sectors which have undergone positive economic development have also been able to register a positive development regarding energy efficiency. For example, the food sector has grown by $100 \%$ over the past years (from EUR 3,450 million in value added in 2004 to EUR 6,950 million in 2014), while its energy consumption has fallen by around $35 \%$. Particularly striking are developments in the 
water and waste sector, where energy intensity has decreased almost sevenfold (to 51,7 kgoe / EUR 1,000), and the metalworking and processing industry by 5.5 times (to 574,3 kgoe / EUR 1,000), the furniture industry by 5.4 times (to $34.8 \mathrm{kgoe} / \mathrm{EUR}$ 1,000), and the chemical industry by about 13 times (to 232.9 kgoe/ EUR 1,000), especially as the value added in these industries increased by 7 times in the water and waste sector, 2.6 times in the metal sector, 3 times in the furniture industry and 5.8 times in the chemical industry.

\section{Conclusions}

The price developments on the energy market and increasing climate problems make it more urgent than ever to fully exploit the countries great energy potential and to conserve energy. Energy efficiency has great potential in Romania, as Romania has set itself the goal of improving energy efficiency in addition to a balanced energy mix, and the EU objectives set that goal. The promotion of energy efficiency and the rational use of energy at national level are becoming increasingly important in Romania. The two main end consumers are the housing and the industry sector, with services increasing their consumption share.

The powerful economic development of Romania led to the adjustment of energy costs to world market levels. Also the increase of competition by becoming part of the single market, determined the industry to develop consciousness regarding energy-saving measures.

The need for effective use of energy is also compounded by the fact that Romania's existing energy commodities such as coal, gas and oil are far from sufficient in the medium and long term to meet national energy needs. Only through the sustainable saving of energy, the trade balance can be relieved when import costs are rising.

The innovative character of the research is given on the one hand by the topicality of the theme, both from the point of view of the theoretical framework energy economics, resource efficiency and decoupling theories being still at an early stage of development - and also because of the research content, the energy sector enjoying both the attention of the university environment as well as that of civil society, the business environment, public administration and the media. The novelty of the topic is the main source of limitations on research, the scientific articles on the subject being relatively limited as opposed to the strategies elaborated in this field.

European governments have responded to warnings and requests on climate change and resource shortages from civil society and subsequently from business environment through two types of measures: some aimed at limiting activities with a negative environmental and wasteful impact, and others to stimulate activities that contribute directly to sustainable development. In the second category are included incentives meant to encourage the efficient use of resources, the production of alternative energy sources and the research and development in these sectors. These have yielded over time more or less satisfactory results. The design of these incentives and strategies is based on defining the relationships between economic, social and technical indicators, relationships that should be further analysed. 


\section{References}

Bartleet, M., \& Gounder, R., 2010, Energy consumption and economic growth in New Zealand: results of trivariate and multivariate models. Energy Policy, 38(7), 3508-3517. doi: 10.1016/j.enpol.2010.02.025

Burcea, F.-C., Ungureanu, E., \& Bâldan, C. F., 2012, Energy Intensity - A Key Indicator for the Economic Development. Annals of the University of Petrosani : Economics, 25-32.

Clodnitchi, R., Deutsch-Rumaenische Industrie- und Handelskammer, 2017, ZMA Energieeffizienz in der Indsutrie

Comisia Nationala de Prognoza, 2017, Prognoza de toamna, www.cnp.ro

Costantini, V., \& Martini, C., 2010, The causality between energy consumption and economic growth: a multi-sectoral analysis using non-stationary cointegrated panel data. Energy Economics, 32(3), 591-603. doi: 10.1016/j.eneco.2009.09.013

European Commission, 2016, Report from the Commission to the European Parliament, the Council, the European Economic and Social Committee, the Committee of the Regions and the European Investment Bank: Clean Energy for All Europeans. COM/2016/0860

Eurostat, 2017, code: tsdec 360

Hristov, T., 2017, Energy audits in the industrial sector, ANRE

INSSE - Romanian National Statistics Institute, 2017, Tempo online; Anuare statistice; Romania in cifre

Leca, A., 2015, Romania needs a strategy for thermal energy. Management and Marketing, 10(1), 3-11.

Lise, W., \& Van Montfort, K., 2007, Energy consumption and GDP in Turkey: Is there a co-integration relationship? Energy Economics, 29(6), 1166-1178. doi: http://dx.doi.org/10.1016/j.eneco.2006.08.010

Menegaki, A. N., 2011, Growth and renewable energy in Europe: a random effect model with evidence for neutrality hypothesis. Energy Economics, 33(2), 257-263. doi: 10.1016/j.eneco.2010.10.004

Ministerul Energiei, 2016, Strategia energetica a Romaniei http://energie.gov.ro/wp-content/uploads/2016/12/Strategia-Energetica-aRomaniei-2016-2030_FINAL_19-decembrie-2.pdf 22.01.2017.

Ministerul Industriilor, Comertului si Energiei, 2007, Strategia energetica a Romaniei http://www.minind.ro/energie/strategia_energetica_a_romaniei_ 2007_2020.pdf

Murafa, C., 2017, The energy performance contract - key towards energy efficiency in Europe? Proceedings of the International Conference on Business Excellence, Volume: 11, Issue: 1, Pages: 103-110

Nicolau, I. (2017) Legal novelties, ANRE 